\title{
Iran's Interests in Afghanistan Provide Opportunities for Cooperation with United States
}

\author{
FOR RELEASE
}

Thursday

June 19, 2014

In many ways, Iran's interests in Afghanistan fall in line with the United States' goals and provide opportunities for cooperation between the U.S. and the Islamic Republic, according to a new RAND Corporation report.

Although relations between Iran and the U.S. have been strained over Iran's nuclear ambitions, both countries have similar goals in wanting to see a stable Afghanistan free of Taliban control. In the event of a nuclear deal between Iran, the United States and its allies, Iran and the U.S. can work together in countering narcotics trafficking in Afghanistan and resolve water disputes between the neighboring nations.

"Many experts are concerned that the departure of most international military forces from Afghanistan will lead to greater instability there, which could be exploited by foreign powers," said Alireza Nader, lead author of the study and senior international policy analyst at RAND, a nonprofit research organization. "Iran does have substantial economic, political, cultural and religious leverage in Afghanistan, and will use that in an attempt to shape a post-2016 Afghanistan. However, there are opportunities for the U.S. to partner with Iran in ways that could benefit all three nations."

The RAND study examines Iran's historical interests in Afghanistan, its current policies in that country and explores the potential implications for U.S. policy. Nader and his colleagues conducted field interviews in Afghanistan and reviewed primary sources in Dari, Persian and English.

Iran has provided Afghanistan with up to $\$ 500$ million for economic reconstruction and is one of Afghanistan's largest trading partners and investors. Its economic activity also has included partnering with other countries, notably India, which Iranian leaders see as a hedge against Pakistani ambitions in the region, as well as a way for Iran to be less isolated.

Iran also has been working diligently to build "soft power" in Afghanistan, building and supporting pro-Iranian schools, mosques and media centers. Afghan schools have received thousands of Iranian books, many of which espouse the values of the Islamic Republic. Its efforts, however, have not won over all segments of the Afghani population. The Pashtuns, who are more closely affiliated with Pakistan, remain wary of Iranian influence and many of the Shia 
Hazara do not favor Iran's theocratic system of governance. In recent years, Shia Hazara political parties have made efforts to not be seen as Iranian proxies.

While many of the tensions between Iran and the U.S. appear to be intractable and tangled in politics in the U.S. and Iran, two pressing issues in Afghanistan - drug trafficking and water usage issues - are relatively nonpolitical and uncontroversial, Nader said. Engaging with Iran on these issues could ease tensions between the two countries and promote stability in Afghanistan, especially in the event of a nuclear deal.

The study, "Iran's Influence in Afghanistan: Implications for the U.S. Drawdown," can be found at www.rand.org. Other authors of the study include Ali G. Scotten, Ahmad Idrees Rahmani, Robert Stewart and Leila Mahnad.

Research for the study was sponsored by a private foundation and was conducted within the International Security and Defense Policy Center of the RAND National Security Research Division. The division conducts research and analysis on defense and national security topics for the U.S. and allied defense, foreign policy, homeland security and intelligence communities and foundations and other nongovernmental organizations that support defense and national security analysis.

- Share on Facebook3

- Share on Twitter

- Share on LinkedIn0

\section{About the RAND Corporation}

The RAND Corporation is a research organization that develops solutions to public policy challenges to help make communities throughout the world safer and more secure, healthier and more prosperous. 